\title{
Historical Thinking and the Human: Introduction
}

\author{
Marek Tamm \\ Professor of Cultural History, School of Humanities, Tallinn University, \\ Tallinn, Estonia \\ marek.tamm@tlu.ee
}

\section{Zoltán Boldizsár Simon}

Assistant Professor, Institute for History, Leiden University, Leiden, the Netherlands

Research Fellow, Faculty of History, Philosophy and Theology,

Bielefeld University, Bielefeld, Germany

zoltanbsimon@uni-bielefeld.de

\begin{abstract}
In recent years the age-old question "what is the human?" has acquired a new acuteness and novel dimensions. In introducing the special issue on "Historical Thinking and the Human", this article argues that there are two main trends behind the contemporary "crisis of human": ecological transformations (related to human-induced climate change and planetary environmental challenges), and technological ones (including advancements in human enhancement, biotechnology and artificial intelligence). After discussing the respective anthropocenic and technoscientific redefinitions of the human, the paper theorizes three elements in an emerging new historicity of the human: first, the move from a fixed category to a dynamic and indeterminate concept, considering the human as a lifeform in movement; second, the extent to which the human is conceived of in its relational dependence on various non-human agents, organic and non-organic; and third, the reconceptualization of the human not as one but as many, to comprehend that we cannot speak of human individuality in the classical biological sense. In the final part, the article addresses the consequences of the redefinition of the human for historical thinking. It makes the case for the need to elaborate a new notion of history - captured by the phrase "more-than-human history", and attuned to an emerging planetary regime of historicity in which historical thinking becomes able to affirm multiple temporalities: digital, technoscientific, sociocultural, human, biological and anthropocenic. The article concludes by recognizing the necessity to venture into a new transdisciplinary knowledge economy, appropriate
\end{abstract}


for making sense of the contemporary constellation of the entangled human, technological and natural worlds.

\section{Keywords}

Anthropocene - historical thinking - human - more-than-human history - planetary regime of historicity - technology - transhumanism - posthumanism

What man is, only his history can tell him. WILHELM DILTHEY ${ }^{1}$

"What is the human?" seems to be the central question in our age. A historical intervention would right away point out that, needless to say, this interrogation is not new: philosophers and others have contemplated the human being for thousands of years. To begin with, "What is man?" is asked in both Job (7:17) and the Psalms (8:4). Then, the question of the human was a particularly important issue in the age of Enlightenment too. According to Kant, "the greatest concern of the human being is [...] to rightly understand what one must do in order to be a human being". ${ }^{2}$ Kant claims that every truly important question that humans can ask is fundamentally a question about human beings, about what we can know, or should do, or may hope. ${ }^{3}$ Since the 193 os, discussions about "the crisis of man" have been held in various forms in the Western world,

1 Wilhelm Dilthey, "Dream” [1903], trans. RamonJ. Betanzos and Rudolf A. Makkreel, in Wilhelm Dilthey, Selected Works, vol. 6: Ethical and World-View Philosophy, eds Rudolf A. Makkreel and Frithjof Rodi (Princeton and Oxford: Princeton University Press, 2019), 170. German original: "Was der Mensch sei, sagt ihm nur seine Geschichte." Wilhelm Dilthey, Gesammelte Schriften, Bd. 8: Weltanschauungslehre: Abhandlungen zur Philosophie der Philosophie (Stuttgart: B.G. Teubner, 1962), 226.

2 The quote is from a set of handwritten notes written in 1764 in Kant's personal copy of Observations on the Beautiful and Sublime, see Immanuel Kant, Gesammelte Schriften, Bd. 20, Abtheilung III: Handschriftlicher Nachlass, Bd. 7 (Berlin: Walter de Gruyter, 1942), 41. Quoted by Patrick R. Frierson, What is the Human Being (Kant's Questions) (London and New York: Routledge, 2013), 3 .

3 Frierson, What is the Human Being, 5. 
related to totalitarianism, technics, the camps, and the nuclear bomb. ${ }^{4}$ Michel Foucault argued famously in 1966 that each new epistemological regime conjures novel images of the human and that this "new wrinkle in our knowledge", the human as the common object of study constituted by the "human sciences" and invented a couple of centuries ago, "will disappear again as soon as that knowledge has discovered a new form". ${ }^{5}$

However, in the last few decades, the human has acquired a new acuteness and novel dimensions. Rosi Braidotti opens her recent book by stating that "in contemporary society the human has become a question mark. Who or what counts as human today?" 6 George Lakoff writes in the same vein, but from a different perspective: "There is a revolution going on, a revolution in our understanding of what it is to be a human being. [...] As a society, we have to rethink what it fundamentally means to be human."7 The new crisis of the human is well captured by Giorgio Agamben who argues that the prevailing idea of the human has been strategically built upon the separation between the human and the natural. He writes: "Homo sapiens, then, is neither a clearly defined species nor a substance; it is, rather, a machine or device for producing the recognition of the human." ${ }^{\prime 8}$ Agamben sees that throughout history this "anthropological machine" contributes to human self-understanding in opposition to the non-human: "Homo is a constitutively 'anthropomorphous' animal [...], who must recognize himself in a non-man in order to be human." ${ }^{9}$ There is an increasing consensus among scholars in various fields that this idea of the human, ontologically distinct from all non-humans, is precisely one of the main drivers of the contemporary planetary crisis. "If this is the case", Samantha Frost contends, "then a fundamental reconceptualization of what humans are, of what the human might be, could provide resources for cogent,

4 For an interesting recent discussion with references to major contributions, see Mark Greif, The Age of the Crisis of Man: Thought and Fiction in America, 1933-1973 (Princeton and Oxford: Princeton University Press, 2015).

5 Michel Foucault, The Order of Things: An Archaeology of Human Sciences (New York: Vintage, 1970), XXIII.

6 Rosi Braidotti, Posthuman Knowledge (Cambridge: Polity, 2019), 1.

7 George Lakoff, "Foreword", in Benjamin K. Bergen, Louder Than Words: The New Science of How the Mind Makes Meaning (New York: Basic Books, 2012), pp. IX-X.

8 Giorgio Agamben, The Open: Man and Animal, trans. Kevin Attell (Stanford: Stanford University Press, 2004), 26. Amanda Bees and Charlotte Sleigh have argued recently in the same spirit that "it is the act of inclusion - not the content of what, or who, is included that frames humanity". See Amanda Bees and Charlotte Sleigh, Human (London: Reaktion, $2020), 22$.

9 Agamben, The Open, 27. 
creative, and robust engagement with the difficult question of how we should transform the ways we live."10

In the coming pages, we will present some ideas for a new conceptualization of the human and situate it with a simultaneous redefinition of historical thinking. In the first step, however, it seems necessary to briefly discuss the main ontological and epistemological shifts behind this new interrogation. We would argue that there are two main trends that explain the new crisis of the human: ecological transformations, related to human-induced climate change, the extinction of species, ocean acidification and various other environmental problems, and technological transformations, including advancements in human enhancement, genome editing, biotechnology and artificial intelligence. The first series of transformations belongs to the theoretical realm of anthropocenic redefinitions of the human that include not only the transdisciplinary Anthropocene debate but also the anti-anthropocentric current in the human and social sciences, while the second series offers a technoscientific redefinition, addressed theoretically by transhumanism and interdisciplinary discussions of engineering the human condition.

\section{Anthropocenic Redefinitions of the Human}

The Anthropocene, popularized as a concept by Paul Crutzen and Eugene Stoermer in 2000,11 was coined to apprehend the growing realization that human impacts on essential planetary processes have become so profound that they have fundamentally altered the state of the Earth system and have driven our planet out of the Holocene epoch..$^{12}$ While the Anthropocene has not yet been approved officially by relevant scientific bodies as a new geological time unit, the data assembled so far clearly shows

that the Anthropocene is geologically real and represents a substantial change in the Earth System from Holocene conditions. This change is reflected in a distinct and globally near-synchronous body of strata

\footnotetext{
10 Samantha Frost, Biocultural Creatures: Toward a New Theory of the Human (Durham and London: Duke University Press, 2016), 3.

11 Paul J. Crutzen and Eugene F. Stoermer, "The 'Anthropocene", IGBP Global Change Newsletter, 41 (2000), 17-18; Paul J. Crutzen, "Geology of Mankind", Nature, 415 (2002), 23.

12 For a most recent and authoritative discussion of the Anthropocene as geological time unit, see Jan Zalasiewicz, Colin N. Waters, Mark Williams and Colin P. Summerhayes (eds), The Anthropocene as a Geological Time Unit: A Guide to the Scientific Evidence and Current Debate (Cambridge: Cambridge University Press, 2019).
} 
characterised by a wide array of stratigraphic proxy markers, a unit that is most clearly recognisable as a globally near-synchronous unit with a boundary placed somewhere around the 1950s. ${ }^{13}$

This does not mean that the Anthropocene refers to something that has only recently been discovered, but rather that it denotes "a new way of organizing knowledge pertaining to the relationship between humans and nature". ${ }^{14}$ The notion that collective human action is altering the Earth has been debated since early modern period and the idea of "human epoch" is as old as geology. ${ }^{15}$ But it is only during the last decade that we have witnessed the extent to which the idea of the Anthropocene is challenging the ontological and epistemological certainties upon which the human world-making project reposes. While we think that meaningful exchange on the Anthropocene begins with a recognition of the work and definitions of Earth system science, we also agree with the more humanities-oriented approach contending that "the best way to understand the Anthropocene is not as a settled concept and not as an accomplished theory but an open question". ${ }^{16}$ The Anthropocene is a contested concept "good to think with" - it puts previous knowledges into a new constellation, and opens up a new space for thinking about fundamental issues across traditional disciplinary divides. From a humanities perspective, the Anthropocene heralds nothing less than "a new way of being-in-the-world"17 or a "new human condition". 18

Indeed, the main lesson of the Anthropocene consists in shaking the very idea of what it means to be human, investing the Homo sapiens with unprecedented ecological and geological powers and responsibilities. According to Peter Sloterdijk,

the proliferation of this concept can mainly be traced back to the fact that, under the guise of scientific neutrality, it conveys a message of almost unparalleled moral-political urgency, a message that can be

\footnotetext{
13 Zalasiewicz et al. (eds), The Anthropocene as a Geological Time Unit, 285.

14 Pierre Charbonnier, "A Genealogy of the Anthropocene: The End of Risk and Limits", Annales HSS (English Edition), 72:2 (2017), 201.

15 Simon L. Lewis and Mark A. Maslin, The Human Planet: How We Created the Anthropocene (London: Penguin, 2018), esp. ch. 1.

16 Eva Horn and Hannes Bergthaller, The Anthropocene (Key Issues for the Humanities) (London and New York, Routledge, 2020), 31.

17 Horn and Bergthaller, The Anthropocene, 98.

18 Christophe Bonneuil and Jean-Baptiste Fressoz, The Shock of The Anthropocene: The Earth, History and Us, trans. David Fernbach (London and New York: Verso, 2016), 24.
} 
explicitly formulated as follows: human beings have become responsible for the habitation and management of the Earth as a whole, since their presence upon it is no longer more or less seamlessly integrated with it. ${ }^{19}$

The situation is particularly exceptional because while many species have changed the planet before, "there has never before been a geological force aware of its own influence", as David Grinspoon puts it, calling this new situation "the advent of self-aware geological change". 20 "In short, everything is now in play. Every cubic metre of air and water, and every hectare of land, now has a human imprint."21 The question is whether we are able and properly equipped to conceptualize the human role and impact across such a vastly expanded temporal stage and in relation to all life forms on the planet. Or, in the words of Christophe Bonneuil and Jean-Baptiste Fressoz: "What does it mean for us, humans, to have the future of a planet in our hands?"22

While the Anthropocene problematizes the human by bringing it to the centre of the Earth system, at the same time it invites humility in the face of a human dependence upon Earth and its multiple ecological systems. We have to think about and act upon biological and geological processes which are typically understood as lying outside of human reach. Put differently, the Anthropocene forces us to radically rethink the scope of human agency and to see humans in the context of and being intertwined and entangled with planetary processes. The Anthropocene means, in Bruno Latour's words, "a thorough 'redistribution' of all the agencies composing the world. It is such a redistribution that explains why the very notion of 'humanity' has to be redesigned."23

19 Peter Sloterdijk, What Happened in the Twentieth Century? Towards a Critique of Extremist Reason (Cambridge: Polity Press, 2018), 1.

20 David Grinspoon, Earth in Human Hands: Shaping Our Planet's Future (New York and Boston: Grand Central Publishing, 2016), x and XI. Cf. Gísli Pálsson et al., "Reconceptualizing the 'Anthropos' in the Anthropocene: Integrating the Social Sciences and Humanities in Global Environmental Change Research", Environmental Science \& Policy, 28 (2013), 8: "But surely the most striking feature of the Anthropocene is that it is the first geological epoch in which a defining geological force is actively conscious of its geological role." David Wood, Deep Time, Dark Times: On Being Genealogically Human (New York: Fordham University Press, 2019), 1: "Never before has a species possessed both a geological-scale grasp of the history of the earth and a sober understanding of its own likely fate." Clive Hamilton, "Human Destiny in the Anthropocene", in Clive Hamilton, Christophe Bonneuil and François Gemenne (eds), The Anthropocene and the Global Environmental Crisis: Rethinking Modernity in a New Epoch (New York and London: Routledge, 2015), 34. Bonneuil and Fressoz, The Shock of The Anthropocene, XIII.

23 Bruno Latour, "Sharing Responsibility: Farewell to the Sublime", in Bruno Latour with Christophe Leclercq (eds), Reset Modernity! (Cambridge, MA, and London: The MIT Press, 2016), 168. 
Latour's words pertain to the fundamental ambivalence of the anthropocenic redefinition of the human. For the recognition of the scaling up of human powers to planetary-level agency is accompanied by a simultaneous urge to scale down and to view ourselves as acting in a web of planetary life instead of acting as a domineering species - all this without losing sight of intra-species differentiated responsibilities and vulnerabilities. Such anti-anthropocentric drive animates a growing body of intersecting new knowledge formations from an emerging new materialism across disciplines (including historical scholarship) through environmental humanities to posthumanist approaches. ${ }^{24}$

The relationality entailed by seeing the human being entangled in a larger arrangement of life most certainly opens up modes of thinking that hope to break with old habits of thought. Hence Timothy Morton's concise assessment that "the Anthropocene is the time at which the human becomes truly thinkable in a non-teleological, non-metaphysical sense". ${ }^{25}$ Morton is seconded by Rosi Braidotti: "What or who is the human today can only be understood by incorporating the post-human and non-human dimensions." ${ }^{26}$ We believe indeed that the old question of "what is the human" requires, in the time of the Anthropocene, a new answer, informed by the anthropocenic redefinition of the human that equally takes into account the Earth System Science (ESS) view on humans becoming a force of nature and the anti-anthropocentrism of the human and social sciences. But to make things more complex, it seems equally important to bring in insights from transhumanism and from debates related to human enhancement and artificial intelligence, to which we turn in the following section.

\section{2 Technoscientific Redefinitions of the Human}

Given the fact that technology and technoscientific advancements are primary drivers behind the perception of humans reaching planetary-scale agency, the redefinition of the human as a technologically malleable being is not unrelated

\footnotetext{
24 See, respectively, Diana Coole and Samantha Frost (eds), New Materialisms: Ontology, Agency, and Politics (Durham: Duke University Press, 2010); Timothy J. LeCain, The Matter of History: How Things Create the Past (New York: Cambridge University Press, 2017); Ursula K. Heise, Jon Christensen, and Michelle Niemann (eds), The Routledge Companion to the Environmental Humanities (London and New York: Routledge, 2017); Francesca Ferrando, Philosophical Posthumanism (London: Bloomsbury Academic, 2019).

25 Timothy Morton, Humankind: Solidarity with the Nonhuman People (London and New York: Verso, 2017), 41.

26 Braidotti, Posthuman Knowledge, 1.
} 
to the anthropocenic one. They even share the aforementioned fundamental ambivalence in their approach to the human - the simultaneity of becoming more exceptional than ever and far less central than ever - although with very different emphases. In both cases, the exceptionality of the increased human powers is accompanied by the reverse possibility of deflating the importance of the human lifeform and potentially even rendering it obsolete. Yet, unlike in anthropocenic and anti-anthropocentric discussions, contemporary technological and technoscientific redefinitions of the human are more focused on what they conceive of as a biologically defined human potentially giving way to what they consider even higher forms of intelligent life, biological or non-biological. True enough, this still entails seeing the human in a larger web of life (in this case, even cosmic rather than planetary), but only in order to point onwards to a new other-than-human exceptionality in the most radical versions.

For the sake of simplicity and comprehensibility, it seems reasonable to introduce technoscientific redefinitions of the human by pointing at the fact that they come at various degrees in a complex discussion that - despite our practices of habitual labelling - largely defies established political positions and ideologies. This does not mean of course that those who argue in favor of actively acting on the technological malleability of the human do not themselves apply political and ideological labels to their own approaches. It only means that the political self-labelling of those invested in technologically engineering the human condition may be just as misleading as the labels they receive. On a spectrum of radicality in their political self-understandings, one can find, merely among self-identified transhumanist approaches aiming at overcoming human biological limitations by having recourse to new technologies, the allegedly apolitical assertion that "transhumanism does not support any particular party, politician or political platform"; ${ }^{27}$ a modest self-identified liberal democratic stance; ${ }^{28}$ a sharper effort to rewrite the traditional Left-Right division with one revolving around "precautionary" and "proactionary" poles; ${ }^{29}$ or F.M. Esfandiary's condemnation, from as early as 1970, of all old political ideologies as essentially conservative when compared to an emerging technoscientific revolutionary view:

27 The quote is from an early version of The Transhumanist Declaration, a short document featuring as an appendix to Nick Bostrom, "A History of Transhumanist Thought", Journal of Evolution and Technology, 14:1 (2005), 21.

28 James Hughes, Citizen Cyborg: Why Democratic Societies Must Respond to the Redesigned Human of the Future (Cambridge, MA: Westview Press, 2004).

29 Steve Fuller and Veronika Lipinska, The Proactionary Imperative: A Foundation for Transhumanism (Basingstoke: Palgrave Macmillan, 2014). 
Who are the new revolutionaries of our time? They are the geneticists, biologists, physicists, cryonologists, biotechnologists, nuclear scientists, cosmologists, radio astronomers, cosmonauts, social scientists, youth corps volunteers, internationalists, humanists, science-fiction writers, normative thinkers, inventors ... They and others are revolutionizing the human condition in a fundamental way. Their achievements and goals go far beyond the most radical ideologies of the Old Order. ${ }^{30}$

Yet, just how revolutionary the various approaches to the technoscientific redefinition of the human are hinges more on the ultimate aims they hope to achieve and their scopes of application. As their shared basis, all approaches agree on applying the work of the sciences and advanced technologies to alter the human condition. But they greatly differ both in degree and in kind in their modes of reimagining and engineering the human. As available options, future scenarios and their societal, cultural, ethical, and political consequences are incredibly varied. They range from company initiatives for "insideable" chip implants under employees' skin at workplaces to the anticipation of the social order of an era of brain emulations (Ems) as new lifeforms, emerging upon the possible availability of the technology to emulate human brains. ${ }^{31}$ Here, in line with our purposes in this essay, we would like to confine ourselves to a few indicative mentions.

To begin with an existing practice that may likely be among the least contentious ones, consider prosthetic technologies in a medical context. Whereas few would argue that we need to stop using prosthetic implants, linking the issue with the question of "human enhancement" through the application of advanced technologies stirs great controversies right away by raising the question of boundaries. As Sheila Jasanoff warns, it is hard to pinpoint where medicine ends and enhancement begins: "medicine's primary mission is to make sick people whole and at-risk people stay healthy, but the line between using gene therapy to cure defects and genetic enhancement to endow people with superhuman capabilities is blurred and controversial". ${ }^{32}$ Indeed, bringing in the enhancement aspect raises the question whether a line can

30 Quoted in Bostrom, "A History of Transhumanist Thought", 11.

31 Stéphanie Gautier, 'I've Got You Under My Skin' - The Role of Ethical Consideration in the (Non-)Acceptance of Insideables in the Workplace", Technology and Society, 56 (2019), 93-108; Robin Hanson, The Age of Em: Work, Love, and Life when Robots Rule the Earth (Oxford: Oxford University Press, 2016).

32 Sheila Jasanoff, The Ethics of Invention: Technology and the Human Future (New York: W.W. Norton \& Company, 2016), 120. 
or cannot be drawn between medical treatment and enhancement, ${ }^{33}$ just as well as the question whether the underlying motive of enhancement is rather the elimination of disability (accompanied by a devaluation of persons with disabilities). ${ }^{34}$ Either way, the potential challenges are only growing as the conversation moves toward the question of human enhancement in the broadest terms - be the enhancement cognitive, physical, ethical, emotional, sensory, or otherwise, and be it due to the application of biotechnologies, nanotechnologies, or otherwise. ${ }^{35}$ For an example, think of concerns raised about the use of enhancement technologies in a military context, even concerning moderate interventions. ${ }^{36}$

On the other hand, in the last two decades or so it is the aforementioned transhumanist movement that has become associated with more radical versions of human enhancement. As the idea of enhancement is necessarily relative to whatever is considered as being the current condition, it is difficult to identify what counts as a radical intervention into the human condition. Hence the rather vague definitions of moderate and radical enhancements by Nicholas Agar, who claims that whereas "moderate enhancement improves significant attributes and abilities to levels within or close to what is currently possible for human beings", "radical enhancement improves significant attributes and abilities to levels that greatly exceed what is currently possible for human beings" ${ }^{37}$ Agar's distinction conveys again a sense that human enhancement is a matter of degree. And this may indeed be true of transhumanist predecessors

33 See Frances M. Kamm, "Is There a Problem With Enhancement?", The American Journal of Bioethics, 5:3 (2005), 5-14. Kamm argues that the treatment-enhancement distinction is implied by the views of Michael Sandel (typically linked with bioconservatism in the human enhancement debate). Kamm's criticism is directed at the article Michael J. Sandel, "The Case Against Perfection: What's Wrong with Designer Children, Bionic Athletes, and Genetic Engineering", The Atlantic Monthly, 293:3 (2004), 51-62. Available at: https:// www.theatlantic.com/magazine/archive/2004/04/the-case-against-perfection/302927/ (accessed 16 August 2020). Cf. also the later book version, Michael J. Sandel, The Case against Perfection: Ethics in the Age of Genetic Engineering (Cambridge, MA: The Belknap Press of Harvard University Press, 2007).

34 Melinda Hall, The Bioethics of Enhancement: Transhumanism, Disability, and Biopolitics (Lanham: Lexington Books, 2017).

35 For an overview of positions, see Julian Savulescu and Nick Bostrom (eds), Human Enhancement (Oxford: Oxford University Press, 2009).

36 Heather A. Harrison Dinniss and Jann K. Kleffner, "Soldier 2.0: Military Human Enhancement and International Law", in Wolff Heintschel von Heinegg, Robert Frau and Tassilo Singer (eds), Dehumanization of Warfare: Legal Implications of New Weapon Technologies (Cham: Springer, 2018), 163-205.

37 Nicholas Agar, Truly Human Enhancement: A Philosophical Defense of Limits (Cambridge, MA: MIT Press, 2014), 2. 
and the earliest transhumanists, such as Julian Huxley, John Burdon Sanderson Haldane, and John Desmond Bernal, whom Tirosh-Samuelson calls "British Prophets of Transhumanism". The "prophets" had various ties to eugenics, and their commitment to a developmental scenario of gradual betterment over time is most certainly indicated by their following views:

the notion that humanity is at the early phase of its evolutionary process, a notion that comes mainly from Huxley; the emphasis on the human capacity to engineer its material environment and itself; the belief that the salvation of humanity can come only from science and technology; and the fascination with the emergence of collective intelligence that will actualize the immense and yet largely untapped potential of the human mind. ${ }^{38}$

Yet there are good reasons to think that the radicality of enhancement scenarios in transhumanist agendas represents a transformation that is more of a matter of kind. Briefly put, transhumanist aspirations hardly fit Agar's definition of radical enhancement in that they aim at something more profound than "exceeding" greatly current human possibilities. They aim at exceeding human biological limitations, not merely human possibilities, even though, in a somewhat twisted manner, exceeding biological limitations is typically presented as opening up new possibilities even towards nonbiological forms of life. Accordingly, the posthuman of transhumanism (not to be confused with the anti-anthropocentric subjectivity of critical posthumanism) as a redefined and "radically enhanced human" arises out of the recognition that "the range of thoughts, feelings, experiences, and activities accessible to human organisms presumably constitute only a tiny part of what is possible". ${ }^{39}$

The reference to humans and "human organisms" in the above quote from Nick Bostrom, just as his mention of "the human mode of being" in the subsequent sentence, ${ }^{40}$ perfectly testifies to the aspiration of seeking that which lies beyond the human condition as we know it. Despite the vocabulary of human enhancement, the ultimate horizon of transhumanism is not an improvement of the human but something beyond it, something that is even cognitively

38 Hava Tirosh-Samuelson, "Science and the Betterment of Humanity: Three British Prophets of Transhumanism", in Hava Tirosh-Samuelson and Kenneth L. Mossman (eds), Building Better Humans? Refocusing the Debate on Transhumanism (Frankfurt am Main: Peter Lang, 2011), 78.

39 Nick Bostrom, "Transhumanist Values", Journal of Philosophical Research, 30, issue supplement (2005), 4.

40 Bostrom, "Transhumanist Values", 4. 
inaccessible to our human limitations. If Apolline Taillandier is right, then the last two decades of transhumanist rise to prominence and the "human enhancement" agenda have already tamed earlier technoscientific visions of the future: "the posthuman was recast as a univocally progressive notion: predictions of individual self-transformation, unabashed optimism, and horizons of global disruption were replaced with prospects of gradual evolution through reproductive choice, a careful attitude towards technological risk, and an underlying motif of technological convergence". ${ }^{41}$ It is equally possible, however, that the aspirations remained the same as they were in the time of Esfandiary, quoted earlier. Hitting the mainstream agenda and becoming an everyday subject of public debates and cinematic experiences, technoscientific redefinitions of the human must necessarily have become more cautious in their framings.

For transhumanist visions of the future, together with futures of artificial general intelligence, still contain most often the horizon of "global disruption", an irreversible turning point. As the result of an exponential process of technological progress, the event of transition to the posthuman future has been enhanced into the notion of "technological singularity". The concept, used by Vernor Vinge in 1993 at a NASA conference and made popular by Ray Kurzweil in the early 200os, refers to the hypothetical moment where the exponential curve of technological evolution reaches the point where unprecedented changes take place in the blink of an eye. ${ }^{42}$ Ray Kurzweil defines this moment in the following terms: "It's a future period during which the pace of technological change will be so rapid, its impact so deep, that human life will be irreversibly transformed". ${ }^{43}$ After the event, life will take a turn that is incomprehensible for humans, and "we ordinary human beings are not structurally able to foresee, let alone understand, what will happen after the advent of the technological singularity". 44

We believe that answers to the question of the human today must consider the multitude of both anthropocenic and technoscientific redefinitions of the human. It is very unlikely that any one of the aforementioned scenarios

$41 \quad$ Apolline Taillandier, "From Boundless Expansion to Existential Threat: Transhumanists and Posthuman Imaginaries", in Jenny Andersson and Sandra Kemp (eds), Oxford Twenty-First Century Approaches to Literature Futures (Oxford: Oxford University Press, forthcoming).

42 Vernor Vinge, "The Coming Technological Singularity: How to Survive in the Post-Human Era" (1993), available online: https://edoras.sdsu.edu/ vinge/misc/singularity.html (accessed 28 July 2020).

43 Ray Kurzweil, The Singularity Is Near: When Humans Transcend Biology (New York: Viking, 2005), 9 .

44 Roberto Manzocco, Transhumanism - Engineering the Human Condition: History, Philosophy and Current Status (Cham: Springer, 2019), 225. 
becomes dominant or that one will overshadow all others. It seems more probable that the human will transform and transition in extremely complex ways that reflect a large variety and mixture of both anthropocenic and technoscientific redefinitions, not to mention that which remains unforeseen and unforeseeable.

What are the ways to make sense of the human in light of these major ontological, epistemological and biological transformations? We aim to synthesize here briefly the most prevalent answers from our perspective. Thomas Schwarz Wentzer and Cheryl Mattingly write felicitously that "human life has maneuvered itself into a position which requires a repositioning of what we the members of this species - had previously taken to be the matrix of any understanding of human life".45 There is no doubt that every dimension of human life will feel and is already feeling the effects of rapid ecological and technological changes, which means that our relationships with nature, with technology, and with each other will be progressively reworked. We will have to elaborate new forms of interspecies coexistence in biosocial, ecological and technological networks. Or, as Gísli Pálsson claims, humans have to "reinvent themselves in a new sense and on a fundamentally new scale, deliberately altering their bodily constitution and development by exchanging genes, tissues, and organs with both conspecifics and other organisms". ${ }^{46}$ In what follows, we will single out three elements in an emerging new historicity of the human as implied by recent ways of humans reinventing themselves: first, the move from a fixed category to a dynamic and indeterminate concept, considering the human as a lifeform in movement; second, the extent to which the human is conceived of in its relational dependence on various non-human agents, organic and non-organic; and third, the reconceptualization of the human not as one but as many, to comprehend that we cannot speak of human individuality in the classical biological sense.

The first step in reconceptualizing the human is to move from a biologicallyculturally pregiven or fixed category to a dynamic and indeterminate concept.

45 Thomas Schwarz Wentzer and Cheryl Mattingly, "Toward A New Humanism: An Approach from Philosophical Anthropology", HAU:Journal of Ethnographic Theory, 8:1/2 (2018), 146.

46 Gísli Pálsson, "Biosocial Relations of Production", Comparative Studies in Society and History, 51:2 (2009), 4. See also Tim Ingold and Gísli Pálsson (eds), Biosocial Becomings: Integrating Social and Biological Anthropology (Cambridge: Cambridge University Press, 2013). 
Considering the human being as a lifeform in movement points at the historicity of the human, a core concern for this special issue, and, as one could point out, a core concern also for historical thinking already in the last two centuries. Yet the dynamics of the human we have in mind means something very different from what has been associated with modern historical thinking and the modern discipline of history, which, according to the famous definition of Marc Bloch, was a science investigating the human in time, that is, the changing human world ${ }^{47}$ While the historicity of the human Bloch meant was a historicity of human lifeworlds, actions, thoughts, feelings, concerns, and so forth, recent redefinitions of the human uphold the historicity of the human species in relation to other lifeforms. In other words, the historicity of the human today is the historicity of a naturalcultural being that may take a variety of shapes depending on the character of the expected, desired, or actively facilitated transformation.

In technoscientific scenarios that foreground a biological transformation of the human, the ultimate prospect of the disruptive event represents a radical historicity that eventually leaves behind human modes of existence to give way to modes of existence which are better-than-human, ${ }^{48}$ or to supposedly higher forms of life such as superintelligence. ${ }^{49}$ In support of less extreme but also comparatively radical scenarios, their historicity can be pointed out in the language of rights. To legitimize transhumanist aspirations of enhancement, Anders Sandberg argues in favour of a "morphological freedom":

From the right to freedom and the right to one's own body follows that one has a right to modify one's body. If my pursuit of happiness requires a bodily change - be it dying my hair or changing my sex - then my right to freedom requires a right to morphological freedom. My physical welfare may require me to affect my body using antibiotics or surgery. On a deeper level, our thinking is not separate from our bodies. Our freedom of thought implies a freedom of brain activity. If changes of brain structure (as they become available) are prevented, they prevent us from achieving mental states we might otherwise have been able to achieve.

47 Marc Bloch, The Historian's Craft, trans. Peter Putnam (Manchester: Manchester University Press, 1992), 23.

48 Zoltán Boldizsár Simon, "The Story of Humanity and the Challenge of Posthumanity", History of the Human Sciences, 32:2 (2019), 101-120.

49 Nick Bostrom, Superintelligence: Paths, Dangers, Strategies (Oxford: Oxford University Press, 2014). 
There is no dividing line between the body and our mentality, both are part of ourselves. Morphological freedom is the right to modify oneself. ${ }^{50}$

In the conceptual arsenal of the human and social sciences, it is the more familiar notion of "becoming" that attempts to capture a new historicity of the human linked with a fundamental malleability. Rosi Braidotti's most influential critical posthumanism makes the case for the necessity to develop an antianthropocentric (posthuman) subjectivity through developing a philosophy of becoming. ${ }^{51}$ It sees the human within flows of self-organizing becomings as the actualization of the anti-anthropocentric posthuman subjectivity (not to be confused with the literally post-human lifeforms of technoscientific visions) from the becoming-animal (multispecies level) through the becoming-earth (planetary scale) to becoming-machine (technoscientific transformation). Or, as Roland Schaer argues, characterized by its becoming, the human "only happens by being formed, and perhaps, by never ceasing to be formed". 52 Thus, the right question to ask is not "what is the essence of the human?" but rather "what is the human becoming?", as argued, for instance, by the proponents of multispecies ethnography. ${ }^{53}$

In the humanities view, becoming can be applied to the historicity of technoscientific redefinitions of the human too. Consider Ewa Domańska explaining how humans as a species are in a constant process of becoming and change, not least because "contemporary technology gives us tools to improve the human being to become more than human through biological and technological modification - genetic engineering, nanotechnology, prosthesis, regenerative medicine, psychopharmacology, slowing down the ageing process, morphological freedom, mind uploading, and so on". ${ }^{54}$ Joel Garreau makes a further claim in the transhumanist spirit, asserting that we are "in the process of becoming post-human", since our mode of being is increasingly dependent

50 Anders Sandberg, "Morphological Freedom - Why We Not Just Want It, but Need It", in Max More and Natasha Vita-More (eds), The Transhumanist Reader (Malden, MA: Wiley-Blackwell, 2013), 57 .

$5^{1}$ Rosi Braidotti, The Posthuman (Cambridge: Polity, 2013).

52 Roland Schaer, "Présentation", in Pascal Picq, Michel Serres, Jean-Didier Vincent, Qu'est-ce que l'humain? (Paris: Le Pommier, 2003), 9: "Ce que nous savons aujourd'hui, c'est que l'humain n'est pas un donné: il n'advient qu'en se formant, et peut-être, en ne finissant jamais de se former". (All translations are our own, if not otherwise indicated.)

Eben Kirksey, Craig Schuetze, and Stefan Helmreich, "Introduction:Tactics of Multispecies Ethnography”, in Eben Kirksey (ed.), The Multispecies Salon (Durham and London: Duke University Press, 2014), 4.

54 Ewa Domańska, "Posthumanist History", in Marek Tamm and Peter Burke (eds), Debating New Approaches to History (London: Bloomsbury Academic, 2018), 329. 
on complex entanglements with technological networks. ${ }^{55}$ More poignantly phrased, it can be argued that humans and non-humans "co-become" over time, to the point of becoming something other: "the human is nonhuman that should be one of the slogans of future humanities". 56

Although the notion of becoming also activates connotations that may tie it with an old-school Hegelian understanding of historicity as processualdevelopmental unfolding, the idea of "co-becoming" leads directly to the second key component of the new human condition: relationality. It emphasizes the extent to which the new historicity of the human concerns humans as naturalcultural beings, playing out the extent to which the human is already considered in its relational dependence on various non-human agents, organic and non-organic. In her aforementioned attempt to conceptualize a posthuman subjectivity, Braidotti convincingly argues that "the posthuman subject relates at the same time to the Earth - land, water, plants, animals, bacteria - and to technological agents - plastic, wires, cells, codes, algorithms".57 Or, more succinctly put, "[p]osthuman subjectivity is an ensemble composed by zoe-logical, geological and technological organisms - it is a zoe/geo/techno assemblage". 58 This means that the human is always and necessarily morethan-human, enmeshed in living a transversal existence. ${ }^{59}$

Raising the stakes by moving from (post)human subjectivity to the human subject with an emphasis on its material and biological constitution, Samantha Frost has proposed to conceptualize humans as "biocultural creatures", which enables us "to think of humans as perceptually responsive at cellular, organic, regional, and organismic levels, in ways that include neurological stimulation by social and material phenomena (i.e., sense perception and imagination) and in ways that also include more diffuse hormonal or biochemical responses

55 Joel Garreau, Radical Evolution: The Promise and Peril of Enhancing Our Minds, Our Bodies - and What It Means to Be Human (New York: Random House, 2005), 232.

56 Silver Rattasepp, "The Philosophical Discourse on Animals, and the Philosophical Animals Themselves", in Timo Maran et al., Animal Umwelten in a Changing World: Zoosemiotic Perspectives (Tartu: University of Tartu Press, 2016), 56.

57 Braidotti, Posthuman Knowledge, 46.

58 Braidotti, Posthuman Knowledge, 47.

59 If we are not mistaken, the concept of more-than-human was coined by philosopher David Abram in 1996. See David Abram, The Spell of the Sensuous: Perception and Language in a More-Than-Human World (New York: Pantheon Books, 1996). It has been advocated also by cultural geographer Sarah J. Whatmore. See Sarah Whatmore, Hybrid Geographies: Natures Cultures Spaces (London: Sage, 2002), 146-167; see also Whatmore, "Political Ecology in a More-than-Human World: Rethinking 'Natural' Hazards", in Kirsten Hastrup (ed.), Anthropology and Nature (London and New York: Routledge, 2014), 79-95. 
to the ingestion and absorption of the material dimensions of habitats". 60 Alongside Frost's notion, which works on the largest scale by intending to capture the current human condition, many other recent concepts belong to the same semantic family, even if working on smaller scales. One can think of the notion of "viscous porosity" coined by Nancy Tuana ${ }^{61}$ and "transcorporeality" introduced by Stacy Alaimo to emphasize the intensive interchange and material flows between the human body and the environment. ${ }^{62}$

Finally, although the list remains of course open, the new historicity of the human demands its reconceptualization not as one but as many. Thanks to advances in genomic science we have become increasingly aware that our human selfhood includes a variety of microbial communities that play a crucial role in making us who we are. We are a legion, could be summarized in devilish speak. Commenting on the results of the Human Microbiome Project in 2012 by the National Institutes of Health, Julia Adeney Thomas interprets the fact that microorganisms within the human body outnumber human cells by ten to one, claiming that the "project reveals that microbes are neither 'passive riders' nor our incidental allies, aiding digestion and the like. Instead, they are inseparably 'us', more responsible than 'we' are for 'our' existence by most calculations on this micro level" ${ }^{63}$ According to another recent study by Scott Gilbert, we have about 16o major species of bacteria in our bodies which all form complex ecosystems: "[h]uman bodies are and contain a plurality of ecosystems. Our mouths are different ecosystems than our intestines, or our skin, or our airways." ${ }^{64}$ This leads Gilbert to the daring conclusion that we cannot speak of human individuality in the classical biological sense:

We have no anatomical individuality: most of our cells are microbial. No physiological individuality: we are joined in co-metabolism with our microbes. No developmental individuality: the microbes help build our guts and our immune systems. [...] We are not individuals by immune criteria - the microbes actually help make our immune systems, and the

6o Frost, Biocultural Creatures, 148.

61 Nancy Tuana, "Viscous Porosity: Witnessing Katrina", in Stacy Alaimo and Susan Hekman (eds), Material Feminisms (Bloomington, IN: Indiana University Press, 2008), 188-213.

62 Stacy Alaimo, Bodily Natures: Science, Environment, and the Material Self (Bloomington, IN: Indiana University Press, 2010).

63 Julia Adeney Thomas, "History and Biology in the Anthropocene: Problems of Scale, Problems of Value", American Historical Review, 119:5 (2014), 1594.

64 Scott F. Gilbert, "Holobiont by Birth: Multilineage Individuals as the Concretion of Cooperative Processes", in Anna Tsing, Heather Swanson, Elaine Gan, Nils Bubandt (eds), Arts of Living on a Damaged Planet: Ghosts of the Anthropocene (Minneapolis and London: University of Minnesota Press, 2017), M75. 
immune system helps make niches for the microbes in our bodies. [...] Genetic individuality falls apart, too: we have more than 15 o genomes in our bodies beside our eukaryotic inheritance, and these bacteria collectively have many more different genes than we have as human eukaryotes. We are multilineage organisms. Evolutionarily, we are not individuals either: symbionts can provide selectable variation. ${ }^{65}$

One can summarize this brief conceptual sketch of an emerging new notion of the human with a reference to Donna Haraway, paraphrasing Bruno Latour, that strictly speaking "we have never been human", at least from the traditional humanist perspective. ${ }^{66}$ As humans we have always been dependent on other life forms and technologies, and "there is no clear cut categorical distinction between nature and culture, genetic and environmental influences or nature and technology". ${ }^{67}$ However, it is only recently, due to major ecological and technological shifts, that we have become able to formulate the idea that much more so than any other animal, becoming human involves necessarily intimate interaction with more-than-human elements. ${ }^{68}$ It is only now that "we begin to suspect that the human self is chimeric and epiphenomenal"69 and that "we are always a 'we', even when we are alone". ${ }^{70}$ This means that there is a need to think together what we think are (or what we previously thought have been) specifically human activities and the more-than-human world, not least from the historical perspective.

65 Gilbert, "Holobiont by Birth", M83.

66 Donna Haraway, When Species Meet (Minneapolis: University of Minnesota Press, 2008). See also Nicholas Gane, "When We Have Never Been Human, What Is to Be Done? Interview with Donna Haraway”, Theory, Culture \& Society, 23:7/8 (2006), 135158. For other uses of the same expression (mentioned in Haraway's book, p. 305, n. 9), see Eduardo Mendieta, "We Have Never Been Human or, How We Lost Our Humanity: Derrida and Habermas on Cloning", Philosophy Today, sPeP Supplement (2003), 168-175; and Brian Gareau, "We Have Never Been Human: Agential Nature, ANT, and Marxist Political Ecology", Capitalism, Nature, Socialism, 16:4 (2005), 127-140.

67 Stefan Lorenz Sorgner, "Pedigrees", in Robert Ranisch and Stefan Lorenz Sorgner (eds), Post- and Transhumanism: An Introduction (Frankfurt am Main: Peter Lang, 2014), 33.

68 Alan Smart and Josephine Smart, Posthumanism (Toronto: University of Toronto Press, 2017), 2.

69 Genese Marie Sodikoff, "Multispecies Epidemiology and the Viral Subject", in Heise, Christensen, and Niemann (eds), The Routledge Companion to the Environmental Humanities, 114 . 


\section{$4 \quad$ Historical Thinking and the Planetary Regime of Historicity}

What are the consequences of the new historicity and the new notion of the human for historical thinking? And more generally, to what extent do we have to rethink the epistemological foundations of history writing and redefine our current regime of historicity in light of anthropocenic and technoscientific redefinitions of the human? It is our central argument that in our age of ecological and technological transformations we need to elaborate a new notion of history. We think that our new history can reasonably be named morethan-human history, ${ }^{71}$ and that it is framed by our current historical condition, which could reasonably be called a planetary regime of historicity, as Dipesh Chakrabarty suggests by paraphrasing François Hartog's notion of "regimes of historicity".72

We are convinced, like Rob Nixon, that "the imaginative questions that the Anthropocene provokes are accompanied byhistorical ones. The Anthropocene has profound implications for the meaning and object of history, reframing the future by rethinking the past as shaped by a fused biological-geological actor". ${ }^{73}$ It was probably an article of Libby Robin, published in 2007 with the title "History for the Anthropocene" and co-authored with Earth system scientist Will Steffen, that first comprehended the challenge the Anthropocene posed to history writing, arguing for the necessity of integrating scientific and

71 For a longer discussion, see Marek Tamm and Zoltán Boldizsár Simon, "More-than-Human History: Philosophy of History at the Time of the Anthropocene", in Jouni-Matti Kuukkanen (ed.), Philosophy of History: Twenty-First-Century Perspectives (London: Bloomsbury Academic, 2020), 198-215. See also Marek Tamm, "Introduction: A Framework for Debating New Approaches to History", in Marek Tamm and Peter Burke (eds), Debating New Approaches to History (London: Bloomsbury Academic, 2018), 1-19; Zoltán Boldizsár Simon, "Planetary Futures, Planetary History", in Zoltán Boldizsár Simon and Lars Deile (eds), Historical Understanding: Past, Present and Future (London: Bloomsbury Academic, forthcoming).

72 Dipesh Chakrabarty, "The Planet: An Emergent Humanist Category", Critical Inquiry, 46:1 (2019), 1-31; François Hartog, Regimes of Historicity: Presentism and Experiences of Time, trans. Saskia Brown (New York: Columbia University Press, 2015).

73 Rob Nixon "The Anthropocene: The Promise and Pitfalls of an Epochal Idea", in Gregg Mitman, Marco Armiero, and Robert S. Emmett (eds), Future Remains: A Cabinet of Curiosities for the Anthropocene (Chicago and London: The University of Chicago Press, 2018), 5. See also Timothy Morton, Hyperobjects: Philosophy and Ecology After the End of the World (Minneapolis and London: University of Minnesota Press, 2013), 5: “... we are no longer able to think history as exclusively human, for the very reason that we are in the Anthropocene"; Clive Hamilton, Christophe Bonneuil and François Gemenne, "Thinking the Anthropocene", in Hamilton et al (eds), The Anthropocene and the Global Environmental Crisis, 6: "the adoption of the Anthropocene [...] has profound consequences for the way we should now understand and write history". 
humanities knowledges in order to move towards a "history in the service of human co-operation in the interests of the planet". ${ }^{74}$ Similarly, it was probably Dipesh Chakrabarty who first understood the fundamental challenge the ecological transformations posed for historical thinking at its most general and theoretical. In his deservedly famous article "The Climate of History", published in 2009, Chakrabarty contends that "the wall between human and natural history has been breached. We may not experience ourselves as a geological agent, but we appear to have become one at the level of the species. And without that knowledge that defies historical understanding there is no making sense of the current crisis that affects us all."75

"We have fallen into 'deep' history, into deep geological time", Chakrabarty argues, which "carries a certain shock of recognition - recognition of the otherness of the planet and its very large-scale spatial and temporal processes of which we have, unintentionally, become a part." ${ }^{\prime 6}$ More recently, in distinguishing the new emerging "planetary or anthropocenic regime of historicity" from the previous "global regime of historicity", he affirms the integration of scientific and humanities knowledges (that we have seen Robin and Steffen proposed as necessary to come to an understanding of the situation), while also pointing at the difficulties involved:

the anthropocenic regime of historicity as visible in Ess sets humans against a background of relationships and time that necessarily cannot be addressed from within the temporal horizon of human experiences and expectations - that is, from within the global regime of historicity. Yet that is the reconciliation that even Earth system scientists seek to achieve as historians of human futurity. Their understandably human and presentist concerns end up obscuring the profound otherness of the planet that their research also reveals. ${ }^{77}$

74 Libby Robin and Will Steffen, "History for the Anthropocene", History Compass, 5:5 (2007), 1711.

75 Dipesh Chakrabarty, “The Climate of History: Four Theses”, Critical Inquiry, 35:2 (2009), 221.

76 Dipesh Chakrabarty, "The Human Condition in the Anthropocene. The Tanner Lectures in Human Values, delivered at Yale University, February 18-19, 2015", 181. Available online: https://tannerlectures.utah.edu/Chakrabarty\%2omanuscript.pdf (accessed 28 July 2020).

77 Dipesh Chakrabarty, "The Planet: An Emergent Humanist Category", Critical Inquiry, 46:1 (2019), 27. See also Duncan Kelly, Politics and the Anthropocene (Cambridge: Polity, 2019), 113: “... the Anthropocene is clearly a regime of historicity, a way of seeing a problem or concept across multiple layers of time and space, affected by shifting power dynamics in the political present". 
Following Robin's and Chakrabarty's insights, we argue that historical thinking is the key element in making sense of the ongoing planetary crisis, but only if we are able to reconceptualize history as we know it. More specifically, we believe that historical thinking has to be extended to accommodate multiple temporalities in a specific sense, without aiming at unifying them or conflating them with each other.

The most obvious lesson of the Anthropocene, as emphasized by many authors, is the altering of our very idea of time, the reintegration of human and geological temporalities. If the Anthropocene teaches us anything, Stephen W. Sawyer writes, "it is that time and historicity itself are not specifically human". And if the case is so, then "our understanding of how humans relate to that which we previously defined as 'non-human' requires a temporal analytic that situates 'us' (that is the human as well as that which is beyond it) in time". ${ }^{78}$ The question is, how exactly to do this? While situating humans in time is the traditional modern task associated with history, the understanding of the human as the situated subject has been altered; the human has become naturalcultural and more-than-human, as we argued in the previous section. What we consequentially need is a matching planetary expansion of history to accommodate its new subject, while that planetary expansion of history demands that the question of time must be addressed in the first place.

On this logic, the first step in rethinking historical time is to transcend the traditional temporal framework of professionalized historical studies and to expand our temporal horizon deep in the past. Daniel Lord Smail was one of the first to argue that the notion of history should not rest on the invention of writing, but should encompass the entire development of the human species, stretching millions of years into the past. ${ }^{79}$ What we hope to emphasize, however, is the next step: even more than simply extending our horizon of historical time, it is crucial to develop a pluralistic understanding of temporality that is open not only to multiple rhythms and trajectories over different scales but also to multiple conceptions of change. Nigel Clark and Bronislaw Szerszynski, advocating the concept of "planetary multiplicity" in sociology, write to the point: "More than a case of extending the temporalities of the

78 Stephen W. Sawyer, "Time after Time: Narratives of the Longue Durée in the Anthropocene", Transatlantica: Revue d'études américaines, 1 (2015), 12; available on-line: http:// transatlantica.revues.org/7344 (accessed 28 July 2020). See also Eduardo Mendieta, "Anthropocenic Temporalities: The Time of the End and the End of Time", Environmental Philosophy, 17:1 (2020), 125-141.

79 Daniel Lord Smail, On Deep History and the Brain (Berkeley: University of California Press, 2008); Andrew Shryock and Daniel Lord Smail (eds), Deep History: The Architecture of Past and Present (Berkeley: University of California Press, 2011). 
social into geological deep time, what we have been referring to as planetary multiplicity encompasses a wide range of rhythms, intervals, periodicities and singularities." ${ }^{80}$ Although such multiple temporalities have already been characteristic of the modern notion of history, as the work of Helge Jordheim testifies, they could not properly be recognized due to a simultaneous drive to unify them in the very notion of a singular historical process. ${ }^{81}$ With the emergence of new anthropocenic and technoscientific temporalities and historicities, our task is to find ways to recognize them in their multiplicity and complex interrelatedness.

This argument is especially relevant if we consider the technological advancements of our age and pay attention to the other extreme of the existing timescale - the so-called "ultra-fast time". Victor Galaz has recently explored from a philosophical perspective the processes facilitated by algorithms that unfold at temporal scales so fast that they may sometimes overwhelm human cognitive capacities, like in the case of extremely rapid financial trading. "Such phenomena", he argues compellingly, "are also interesting features of the Anthropocene era if we include its very closely aligned technological dimensions". ${ }^{82}$ Yet the issue is not merely that of coming to terms with previously unthinkable paces and tempos of processes that work on previously equally unthinkable scales. If we want to take seriously those "very closely aligned technological dimensions", then we need to take into account the "evental temporality" that informs singularity scenarios and the technological engineering of the human we recounted earlier - especially the ones that postulate the transgression of the human condition. Such "evental temporality", 83 unlike the processual and developmental time of history in the modern regime of historicity, revolves around the occurrence of singular transformative

80 Nigel Clark and Bronislaw Szerszynski, Planetary Social Thought: The Anthropocene Challenge to the Social Sciences (Cambridge: Polity, forthcoming). We quote from the manuscript made available by the authors on Academia.edu: https://www.academia .edu/42776552/Planetary_Social_Thought_The_Anthropocene_Challenge_to_the_Social _Sciences (accessed 27 July 2020).

81 Helge Jordheim, "Introduction: Multiple Times and the Work of Synchronization", History and Theory, 53:4 (2014), 498-518, and his "Return to Chronology", in Marek Tamm and Laurent Olivier (eds), Rethinking Historical Time: New Approaches to Presentism (London: Bloomsbury Academic, 2019), 43-56.

82 Victor Galaz, "Time and Politics in the Anthropocene: Too Fast, Too Slow?", in Frank Biermann and Eva Lövbrand (eds), Anthropocene Encounters: New Directions in Green Political Thinking (Cambridge: Cambridge University Press, 2019), 117.

83 For more on the notion of "evental temporality" see Zoltán Boldizsár Simon, "The Transformation of Historical Time: Processual and Evental Temporalities", in Tamm and Olivier (eds), Rethinking Historical Time, 71-84. 
events, beyond which human cognition stands no chance to fathom the contours of the coming post-evental reality.

Taking newly emerging technoscientific temporalities into account would most certainly entail the reinforcement of the planetarity of our current historical predicament. If not for any other reason, then due to the fact that the technologies that redefine the human, merge human and machine, or point onwards to a singularity, are oftentimes the very same technologies that are invoked in large-scale engineering scenarios aiming to solve or treat the anthropocenic issues deriving from human-induced environmental degradation, climate change, biodiversity loss, and Earth system alterations. ${ }^{84}$ To a certain extent, however, technoscientific temporalities may even point beyond the planetary, or invoke the planetary only in order to see it in a larger framework in which history can even be multiplanetary, ${ }^{85}$ and even the human can be only a transitional phase in a cosmic history of intelligent life. ${ }^{86}$

All in all, the new notion of history has to be able to cope with utterly incommensurable timescales, to situate the digital, technoscientific, sociocultural, human, biological and anthropocenic temporalities. We can only agree with a recent statement made in the context of Anthropocene research that "this heterogeneity of timescales and temporalities calls for completely new forms of historiography", ${ }^{77}$ but we also think that a necessary and equal reflection on technoscientific, transhuman, superintelligence, and singularity temporalities makes the challenge for historiography far more substantial than it is commonly thought.

\section{Conclusion: Philosophy of History and a New Economy of Knowledge}

We argued in the opening section that ecological and technological transformations are reshaping our previous knowledges into an unprecedented constellation and opening up a new space for thinking about fundamental

84 For example, think of de-extinction (aiming at the reintroduction of extinct species due to human activity) or "genetic rescue" (aiming to maintain genetic diversity and species populations in the face of anthropogenic biodiversity loss) through the application of recent biotechnologies. See Amy Lynn Fletcher, De-Extinction and the Genomics Revolution: Life on Demand (Cham: Palgrave, 2020).

85 See Marek Tamm, "Future-Oriented History", in Simon and Deile (eds), Historical Understanding (forthcoming).

86 See Apolline Taillandier, Now for the Long Term: Posthuman Futures and the Limits of the Political, Doctoral Dissertation in Political Science (Paris, Sciences Po, 2020).

87 Horn and Bergthaller, The Anthropocene, 162. 
human-related issues across traditional disciplinary divides. This special issue is an attempt to explore this new space for (historical) thinking. Its starting point and defining feature is a recognition of the necessity to venture into a transdisciplinary knowledge regime, appropriate for the study of the new constellation of the entangled human, technological, and natural worlds. As our modern disciplines are attuned to studying these separately without any of them being solely qualified to address the entanglement, we are yet to develop a new knowledge economy tailored to the study of the entanglement of worlds - a long road on which the first step may very well be finding ways to situate existing knowledge formations and emerging new ones by bridging disciplinary divides. ${ }^{88}$

This is precisely why we invited scholars from various fields and epistemological perspectives to participate in this venture, none of them strictly speaking a philosopher of history in terms of disciplinary codes. While it stands to reason that philosophy of history - understood in its broadest sense - can claim some expertise in studying transformations, we think that many knowledge formations are much further ahead in addressing the questions that should be on the agenda of a rebranded philosophy of history. In our first joint endeavor, we made the case for the necessity for such a rebranded philosophy of history that, by escaping the more than half-century-long confinement of having been reduced to being a philosophy of professionalized historical studies, attempts to develop new ways to address the most pressing planetary challenges of our rapidly changing world and to theorize a new notion of history that is multispecies, multiscalar, and non-continuous. ${ }^{89}$ With this special issue, addressing the question of historical thinking in the face of the ongoing anthropocenic and technoscientific redefinitions of the human across societal practices and knowledge formations, we hope to provide an actual impetus for the formation of such a new philosophy of history.

We are grateful to Ewa Domańska, Sheila Jasanoff, Hava Tirosh-Samuelson, Libby Robin, Bruno Latour and Dipesh Chakrabarty for joining us in this project, just as well as to Jouni-Matti Kuukkanen who offered the journal as a venue for the kind of transdisciplinary discussion through which we, so to speak, intend to bring the ongoing redefinition of the human home to the philosophy of history. As most contributors chose Anthropocene-focused themes,

88 For more on the prospect of the new knowledge regime and the present necessity to bridge even our existing forms of knowledge, see Zoltán Boldizsár Simon, The Epochal Event: Transformations in the Entangled Human, Technological, and Natural Worlds (Cham: Palgrave, 2020), esp. ch. 3 . 
we attempted to play out technological redefinitions a bit more prominently in this introduction. Although the complexity that demands transdisciplinarity is extremely high even when trying to bring anthropocenic and technoscientific transformations of the human and the world separately to the agenda of a new philosophy of history, we believe that, seen together, the challenges are profound to an extent that provides the philosophy of history with multiple ways to potentially join the ongoing discussion.

A more skeptical attitude toward such discussion would likely question why to bring a transdisciplinary discussion to the agenda of such a specific knowledge formation as the philosophy of history. And our answer lies with the ultimate - although somewhat paradoxical - prospect we mentioned earlier: this transdisciplinary venture points toward a more fundamental epistemological landslide, toward a need to rearrange the modes of expertise of existing human knowledge formations. In other words, we need transdisciplinarity, as of now, and we need to situate our existing and continuously renewing modes of expertise with older and with emerging ones, if only in order to point onward to the possibility of kicking off a qualitatively new knowledge economy attuned to studying questions deriving from our qualitatively new predicament. And the case is so even if, eventually, the knowledges we situate today end up perhaps dissolving in new arrangements of knowledge. In working towards such a prospect, we agree with Fredrik Albritton Jonsson that the current situation "force[s] us to reevaluate the structures and orientation of all human knowledge, from the natural sciences to the humanities". ${ }^{90}$ We also are on the same page with Jürgen Renn, who has convincingly claimed in his recent monumental study of the history of human knowledge, that in the time of the Anthropocene we need to build such a new "knowledge economy" that would be able to "transcend not only disciplinary boundaries but perhaps also traditional forms of scientific organization, knowledge production, and education", that is, "an integrative perspective on knowledge that includes not only the physical science of the Earth system but also the interpretative and critical disciplines of the humanities". 91

We cannot remain constrained by our disciplinary knowledge formations that have been established on the premise of studying the human and the nonhuman worlds separately. Hence our hope that this special issue encourages historians and philosophers of history to cultivate new transdisciplinary forms of collaboration and to develop the kinds of historical thinking that are able to make sense of changes over time in a more-than-human world.

9o Fredrik Albritton Jonsson, "A History of the Species?", History and Theory, 52:3 (2013), 464.

91 Jürgen Renn, The Evolution of Knowledge: Rethinking Science for the Anthropocene (Princeton and Oxford: Princeton University Press, 2020), 8-9. 